\title{
Development and evaluation of an extraoral radiographic simulator model
}

\author{
Nádia Assein Arús ${ }^{1}$, Mathias Pante Fontana ${ }^{1}$, Mariana Boessio Vizzotto ${ }^{1}$ and Heraldo Luís Dias da Silveira ${ }^{\text {* }}$ \\ ${ }^{1}$ Department of Surgery and Orthopedics, Federal University of Rio Grande do Sul (Porto Alegre, RS, Brazil), Rua Ramiro Barcelos, 2492/5 floor, Porto Alegre, \\ RS - Brazil
}

\begin{abstract}
Objectives: To describe the development of an extraoral radiographic simulator model that allows the demonstrations of head position and practical training of extraoral radiographic techniques and its usability evaluation by the users.

Methods: It was used a macerated human skull, autopolymerising acrylic resin, orthodontic elastics, screws, polyvinyl chloride pipe and a photograph tripod to build it. After theoretical and demonstration classes, and practical training using the simulator model, twenty-nine professionals from the last five classes of an Oral Radiology Specialization Course filled out a form to evaluate its usability.

Results: the modified SUS (System Usability Scale) final score obtained for usability was eighty-three, indicating high acceptance of the simulator model.

Conclusion: this extraoral radiographic simulator model can be built at a very low cost, is useful for practice extraoral radiographic techniques and it should be encouraging its use as a teaching aid in other institutions.
\end{abstract}

\section{Introduction}

Dental radiology courses work with theoretical classes and an important practical training programme that should provide good understanding of intra- and extraoral techniques as well as of image interpretation to undergraduate and postgraduate levels. These professionals will have the ability to take radiographs, to interpret exams, to evaluate the benefits of radiographic examinations and the cost of exposing the patient to X-rays [1]. Such evaluation will lead to good quality images acquisition by using the lowest possible dose of radiation (as low as reasonably achievable [ALARA]). Considering this principle of radiological protection [2], that limits the number of images obtained to the minimum necessary to obtain essential diagnostic information [3], conducting repeated radiographic examinations of a patient to contribute to student learning is inexcusable. Therefore, simulation-based teaching is a widely growing and popular training option amongst health care students [4], and several study programs on dentistry involve the use of simulators to optimize clinical learning [5-9].

The radiographic models are mannequins with human or artificial bones and teeth arcades with or without soft tissue simulators. It can be mounted on dental chairs or on a tripod and used by students for performing intra- or extraoral radiographic examinations during training, just before taking patient radiographs. However, this didacticpedagogical tool is costly for the education institution. Thus, the aim of this study is to describe the production of an extraoral radiographic simulator model and its evaluation by the users.

\section{Materials and method}

\section{Design and production of the simulator model}

This study was approved by the Research Committee of Dental School, University of Rio Grande do Sul, Brazil (n.27696). It was used a macerated human skull belonging to Oral Radiology Course collection from Dental School, Federal University of Rio Grande do Sul (Porto Alegre, RS, Brazil). The lower jaw was attached to the skull by using orthodontic elastics and a small set of screws fixed in the centre of the mandibular branches and on both sides of the zygomatic bones. This allows easy opening of the mouth of the phantom, whenever necessary. The skullcap was sectioned to enable visualization of anatomical accidents and to facilitate understanding of the projections carried out. To impart training on techniques that involved simulating the head of the patient, the sectioned skullcap was secured by using two orthodontic elastics, which were linked to screws that were fixed on the two temporal bone segments. The magnum foramen was filled with an autopolymerising acrylic resin to create a hole for inserting a plastic screw; the head of this screw was fixed to an approximately 11.81 inch -long polyvinyl chloride pipe segment, which was also filled with the autopolymerising acrylic resin (Figure 1a). Thus, the skull was attached to this pipe when the screw was inserted from the inside. The other extremity of the skull was attached to a metal screw mounted on the platform of a photographic tripod (Figure 1b). This mounting of the phantom on the tripod allowed changing of the skull position as well as conferring the necessary stability (Figure 1c).

\section{Practical training}

After six hours of theoretical classes about extra-oral radiographic techniques, the students from the Oral Radiology Specialization Course

Correspondence to: Heraldo Luis Dias da Silveira, Dental School - Federal University of Rio Grande do Sul, Oral Radiology Division, Rua Ramiro Barcelos, 2492/5 floor, Porto Alegre, RS - Brazil, Tel: 55-51-33085199, E-mail: heraldo@ufrgs.br

Key words: simulation training, radiology, radiography, dentistry

Received: May 24, 2017; Accepted: June 06, 2017; Published: June 09, 2017 


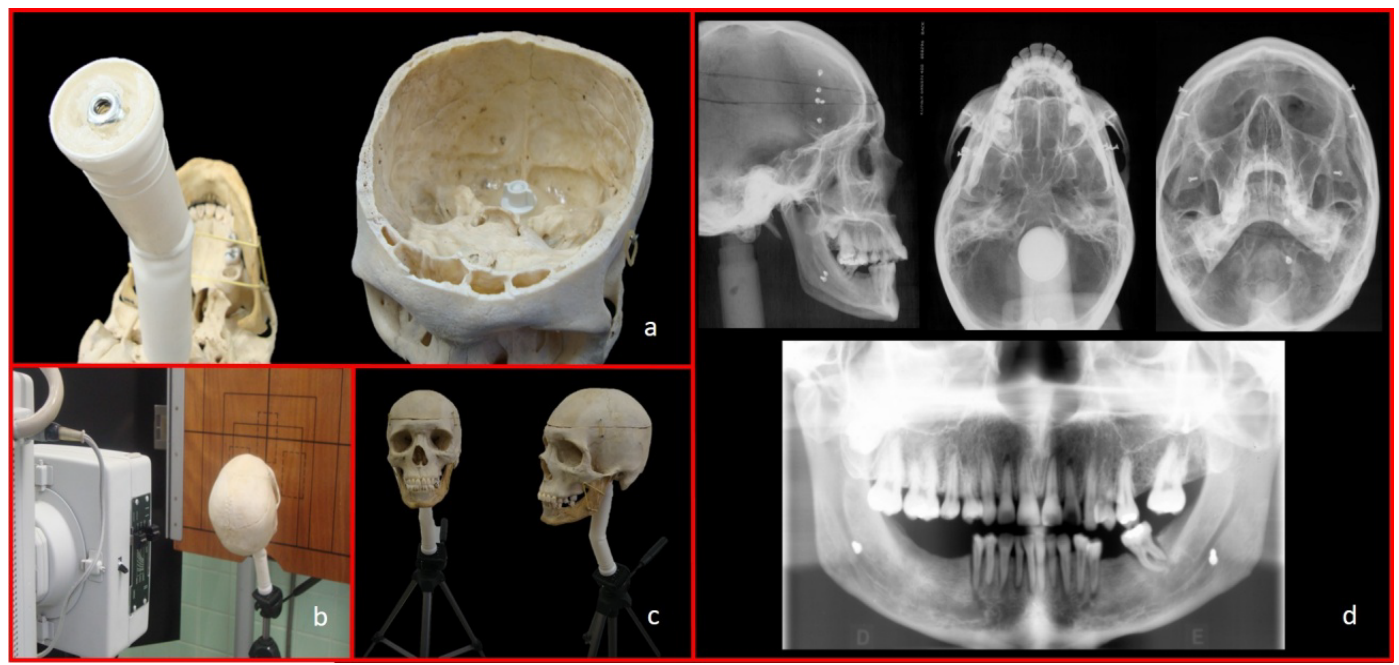

Figure 1. a) The structure of the simulator model; b) Setting the simulator model for extra-oral radiographic techniques; c) The skull and lower jaw mounted on the platform of a photographic tripod; d) Radiographic images (Lateral, Waters, Hirtz and Panoramic) obtained with the simulator model.

at Dental School - Federal University of Rio Grande do Sul (Porto Alegre, RS, Brazil) began the practical training, which consists on a demonstration of the techniques with the simulator model on extraoral and panoramic radiographic units by a teacher. After that, two by two, they used the model to take radiographs themselves (Figure 1d). Each double worked for about eight hours with that system. Only after doing the simulations, they could start to work with patients.

\section{Usability evaluation}

The usability (effectiveness, efficiency, and user satisfaction) of the simulator model was verified by students, using a modified System Usability Scale (SUS) [10]. In a range from 1 to 5, students agreed or disagreed with ten sentences, which covered several aspects, including support and training requirements, complexity and consistency of the model, the simplicity of use during training, and the user's opinion about the method. The form evaluation was elaborated using GoogleDocs (Google Inc, Mountain View, Santa Clara County, CA, USA), and were sent to fifty-three oral radiologists that concluded Oral Radiology Specialization Course at Dental School, UFRGS Brazil, from 2008 until 2016.

\section{Results}

From fifty-three oral radiologists, twenty-nine professionals filled out and sent the form back. Table 1 shows the answers percentage for each sentence from de evaluation form. Noticed almost of them (96.5\%) liked using the simulation model (sentence 1), and $86.2 \%$ believe it is easy to use it (sentence 3 ). Higher divergence between the professionals' answers was about the need of a technical support to be able to use this simulator model, in which $72.4 \%$ disagree and $20.7 \%$ agree with it. The modified SUS final score obtained for usability of the simulator model was eighty-tree, indicating high acceptance.

\section{Discussion}

The simulation model described here allows movement of the skull to positions required for conducting extraoral radiographic examinations from different views such as frontal, lateral, axial and panoramic; these movements can be achieved by ventral, dorsal, and lateral flexion of the skull by using the handles of the photographic tripod (Figure 1c).
Table 1. Modified system uability scale.

\begin{tabular}{|c|c|c|c|c|c|}
\hline & \multirow{2}{*}{\begin{tabular}{|c|}
$\begin{array}{c}\text { Strongly } \\
\text { disagree }\end{array}$ \\
1 \\
\end{tabular}} & & & & \multirow{2}{*}{$\begin{array}{c}\begin{array}{c}\text { Strongly } \\
\text { agree }\end{array} \\
5\end{array}$} \\
\hline & & 2 & 3 & 4 & \\
\hline $\begin{array}{l}\text { 1. I liked using the simulator model } \\
\text { for extraoral radiographic techniques } \\
\text { training }\end{array}$ & $0 \%$ & $0 \%$ & $3.4 \%$ & $31 \%$ & $65,5 \%$ \\
\hline $\begin{array}{l}\text { 2. I found the simulator model } \\
\text { complex }\end{array}$ & $62.1 \%$ & $24.1 \%$ & $6.9 \%$ & $6.9 \%$ & $0 \%$ \\
\hline $\begin{array}{l}\text { 3. I thought the simulator model was } \\
\text { easy to use }\end{array}$ & $3.4 \%$ & $3.4 \%$ & $6.9 \%$ & $34.5 \%$ & $51.7 \%$ \\
\hline $\begin{array}{l}\text { 4. I think that I would need the support } \\
\text { of a technical person to be able to use } \\
\text { this simulator model }\end{array}$ & $41.4 \%$ & $31 \%$ & $6,90 \%$ & $20.7 \%$ & $0 \%$ \\
\hline $\begin{array}{l}\text { 5. I found the manipulation functions } \\
\text { of the skull position in this simulator } \\
\text { model were well integrated }\end{array}$ & $0 \%$ & $3.4 \%$ & $13.8 \%$ & $44.8 \%$ & $37.9 \%$ \\
\hline $\begin{array}{l}\text { 6. I thought there was too much } \\
\text { inconsistency in this simulator model }\end{array}$ & $75.9 \%$ & $10.3 \%$ & $10.3 \%$ & $3.4 \%$ & $0 \%$ \\
\hline $\begin{array}{l}\text { 7. I would imagine that most people } \\
\text { would learn to use this simulator } \\
\text { model very quickly }\end{array}$ & $0 \%$ & $6.9 \%$ & $0 \%$ & $27.6 \%$ & $65.5 \%$ \\
\hline $\begin{array}{l}\text { 8. I found the simulator model very } \\
\text { cumbersome to use }\end{array}$ & $69 \%$ & $13.8 \%$ & $3.4 \%$ & $3.4 \%$ & $10.3 \%$ \\
\hline $\begin{array}{l}\text { 9. I felt very confident using the } \\
\text { simulator model }\end{array}$ & $3.4 \%$ & $0 \%$ & $17.2 \%$ & $55.2 \%$ & $24.1 \%$ \\
\hline $\begin{array}{l}\text { 10. I needed to learn a lot of things } \\
\text { before I could get going with the } \\
\text { simulator model }\end{array}$ & $72.4 \%$ & $17.2 \%$ & $6.9 \%$ & $3.4 \%$ & $0 \%$ \\
\hline
\end{tabular}

The screw placed in the foramen magnum is made of plastic to avoid metal objects in this zone. However, the interference of such metal objects cannot always be eliminated, because for some positioning of the skull necessary for certain procedures, several metal structures of the tripod near the lower part of the acrylic rod may overlap. However, the intention of developing this phantom was not the study of bone anatomy but to offer training on positioning of the patient's head to obtain appropriate radiographic images (Figure 1d).

The absence of soft tissues in the phantom does not allow training on determining parameters such as milliamperage, kilovoltage, and exposure time. However, when obtaining actual standard images, these factors might vary depending on the radiographic equipment and physical characteristics of the patient. 
In addition to the practical uses and easy manipulation of the phantom, we estimated the didactic application of this tool when used for demonstrating different techniques. Moreover, students felt that this tool helped in improving their understanding of the subject. In line with this notion, our team was keen to widely disseminate the idea of production of this simulator model for use as a teaching tool in other institutions, since it can be easily built at a very low cost.

\section{Conclusion}

This developed simulator model can be used for demonstration and training of different extraoral incidences with subsequent evaluations of technical results, providing an interesting didactic-pedagogical instrument at a low cost.

\section{Acknowledgements}

The authors deny any conflicts of interest. We affirm that we have no financial affiliation or involvement with any commercial organization with direct financial interest in the subject or materials discussed in this manuscript, nor have any such arrangements existed in the past three years. Any other potential conflict of interest is disclosed.

\section{References}

1. Vañó E, Rosenstein M, Liniecki J, Rehani MM, Martin CJ, et al (2009) ICRP publication 113. Education and training in radiological protection for diagnostic and interventional procedures. Ann ICRP 39: 7-68. [Crossref]

2. Farman AG (2005) ALARA still applies. Oral Surg Oral Med Oral Pathol Oral Radiol Endod 100: 395-397. [Crossref]

3. American Dental Association (2013) Updated ADA recommendations on dental x-rays J Can Dent Assoc 79: d7. [Crossref]

4. Patel R, Dennick R (2016) Simulation based teaching in interventional radiology training: is it effective? Clin Radiol 72: 266.e7-266.e14. [Crossref]

5. Suebnukarn S, Hataidechadusadee R, Suwannasri N, Suprasert N, Rhienmora P Haddawy P (2011) Access cavity preparation training using haptic virtual reality and microcomputed tomography tooth models. Int Endod J 44: 983-989. [Crossref]

6. He LH, Purton D, Swain M (2011) A novel polymer infiltrated ceramic for dental simulation. J Mater Sci Mater Med 22: 1639-1643. [Crossref]

7. Güth JF, Ponn A, Mast G, Gernet W, Edelhoff D (2010) Description and evaluation of a new approach on pre-clinical implant dentistry education based on an innovative simulation model. Eur J Dent Educ Off J Assoc Dent Educ Eur 14: 221-226. [Crossref]

8. Marras I, Nikolaidis N, Mikrogeorgis G, Lyroudia K, Pitas I (2008) A virtual system for cavity preparation in endodontics. $J$ Dent Educ 72: 494-502. [Crossref]

9. Steinberg AD, Bashook PG, Drummond J, Ashrafi S, Zefran M (2007) Assessment of faculty perception of content validity of PerioSim, a haptic-3D virtual reality dental training simulator. J Dent Educ 71: 1574-1582. [Crossref]

10. Brooke J (2014) SUS - A quick and dirty usability scale. Available from: http://www usabilitynet.org/trump/documents/Suschapt.doc

Copyright: @2017 Arús NA. This is an open-access article distributed under the terms of the Creative Commons Attribution License, which permits unrestricted use, distribution, and reproduction in any medium, provided the original author and source are credited. 